Research Papers

\title{
Improvement of Cleanability of Stainless Steels with Various Surface Chemical Composition by Gaseous Ozone
}

\author{
Kazuhiro TAKAHASHI* and Satoshi FUKUZAKI*
}

*Industrial Technology Center of Okayama Prefecture(5301, Haga, Okayama-shi, Okayama 701-1296)

\begin{abstract}
The effect of gaseous ozone on the cleanability of $316 \mathrm{~L}$ stainless steel was studied using its nonporous particles pretreated with heat-drying at $150^{\circ} \mathrm{C}$, heating at $400^{\circ} \mathrm{C}$, and immersion in $10 \%$ nitric acid. Bovine serum albumin (BSA) was used as the model fouling material. Dried, heated, and $\mathrm{HNO}_{3}$-treated particles showed largely different surface chemical composition and the surface charge density $\left(\sigma_{\mathrm{app}}\right)$. Treatment of the above pretreated particles with $0.2 \%$ gaseous ozone resulted in decreases in the positive $\sigma_{\text {app }}$ values of the particles, with only slight variations in their surface chemical composition. The saturation amounts of BSA adsorbed $\left(\Gamma_{\mathrm{sat}}\right)$ on dried particles decreased significantly $(P<0.05)$ after ozone treatment, whereas those on heated and $\mathrm{HNO}_{3}$-treated particles were not changed. These phenomena were correlated with the degree of a decrease in the positive $\sigma_{\mathrm{app}}$ of the particles after ozone treatment. In continuous cleaning in a plug-flow column fed by a $0.1 \mathrm{M} \mathrm{NaOH}$ solution, it was indicated that the rate and efficiency of BSA desorption from all the particles increased as a result of ozone treatment. Kinetic analysis showed that significantly smaller proportions of a slower-desorbing BSA molecule and significantly higher values of first-order desorption rate constants were obtained for the ozone-modified particles than for their nonozone-modified particles $(P<0.05)$. It was indicated that the cleanability of stainless steel particles could be improved by gaseous ozone treatment irrespective of the surface chemical composition of the original particles.
\end{abstract}

Keywords : Cleanability of Stainless Steel, Surface Chemical Composition, Gaseous Ozone, Surface Charge Density, Binding Strength

\section{Introduction}

The austenitic stainless steels are widely used as construction materials for process plants in the food and pharmaceutical industries ${ }^{1) 3 \text { ) }}$. These alloys fulfill many requirements for food and pharmaceutical machinery, e. g., inert surface to the product, high corrosion resistance to detergents and antimicrobial chemicals, nontoxicity, and mechanical stability. To keep sanitary conditions of process plant, organic residues derived form products and living microorganisms on equipment surfaces should be removed at the end of each set of processing operation by routine cleaning and sterilizing operations. The productcontact surface of stainless steel is commonly treated by mechanical polishing and electropolishing to obtain smooth surfaces or by chemical passivation to improve the corrosion resistance ${ }^{4) \sim 6}$. Although the passive film on stainless steel is damaged to some extent by chemicals such as chlorine during a longterm operation, the passive film spontaneously renews itself in the presence of oxygen and water, where characteristics of the passive film depends on passivation conditions ${ }^{7), 8}$. The surface chemical composition of stainless steel is by far an important factor affecting the degree of fouling and the cleanability compared with its bulk chemical composition since adsorption and desorption behaviors of fouling mate- rials are physicochemical features at solid-liquid interfaces.

Ozone is a powerful oxidizing agent and it is attractive as alternative cleaning and sterilizing agents to chlorine $^{9), 10)}$. Previously, we demonstrated that the surface charge property of $316 \mathrm{~L}$ stainless steel particles could be changed after their exposure to gaseous ozone at low concentrations of 0.05 to $1.0 \%(\mathrm{v} / \mathrm{v})$ with little changes in surface chemical composition ${ }^{11)}$. It was also found that ozone-modified stainless steel particles showed a relatively lower affinity for protein adsorption compared with non-ozone-modified particles $^{11)}$. These findings suggested that oxidizing power of gaseous ozone was useful for the improvement of cleanability of stainless steel surface. The question then arises as to whether the cleanability of stainless steel is improved by gaseous ozone irrespective of the surface chemical composition of original stainless steels. However, a quantitative analysis of the effect of gaseous ozone treatment on the cleanability of stainless steel, and the influence of the surface characteristics on ozone modification have not so far been fully investigated.

The aim of this study is to quantitatively investigate the effect of gaseous ozone treatment on the cleanability of stainless steels with various surface properties. To focus discussion on physicochemical features, we used nonporous stainless steel particles 
fouled with bovine serum albumin (BSA) as the model fouling experiment. Samples of stainless steel particles that have largely different surface chemical composition were prepared by pretreatments with heat-drying, heating, and chemical passivation in $\mathrm{HNO}_{3}$. The cleaning experiment was conducted in a plug-flow column fed by a $0.1 \mathrm{M} \mathrm{NaOH}$ solution, where the hydrodynamic forces are very low. This system is well suited for investigating the effect of physicochemical binding. The curve of BSA desorption was kinetically analyzed as a function of time. The cleanabilities of non-ozone-modified and ozonemodified pretreated particles were compared by evaluating the kinetic constants for BSA desorption.

\section{Experimental}

\section{1 Materials and chemicals}

Nonporous $316 \mathrm{~L}$ stainless steel particles were obtained from The Nilaco Corp. (Tokyo). Before use, stainless steel particles were washed in acetone followed by in ethanol with sonication, and then dried at $150^{\circ} \mathrm{C}$ for $4 \mathrm{~h}$ (non-surface-treated particles). The specific surface area of non-surface-treated particles, as determined by BET method, was $0.40 \mathrm{~m}^{2} / \mathrm{g}$ (mean diameter: $8 \mu \mathrm{m}$ ). Crystalline BSA (Lot M 9 B 4259) was purchased from Nacalai Tesque Inc. (Kyoto) and used as received.

2. 2 Surface pretreatment and ozone treatment

To prepare samples of stainless steel particles with various surface chemical composition, a $20 \mathrm{~g}$-aliquot of stainless steel particles was (i) dried at $150^{\circ} \mathrm{C}$ for $4 \mathrm{~h}$, (ii) heated at $400^{\circ} \mathrm{C}$ for $4 \mathrm{~h}$ under an atmosphere, or (iii) immersed in $200 \mathrm{ml}$ of $10 \% \mathrm{HNO}_{3}$ at $60^{\circ} \mathrm{C}$ for $1 \mathrm{~h}$.

Gaseous ozone of $0.2 \%(\mathrm{v} / \mathrm{v})$ was generated from pure oxygen $(99.999 \%, \mathrm{v} / \mathrm{v})$ by a silent discharge ozonizer as described previously ${ }^{11)}$. A 20-g aliquot of the above surface-pretreated stainless steel particles was placed in a cylindrical glass column $(28 \mathrm{~mm}$ diameter $\times 220 \mathrm{~mm}$ length), and then $0.2 \%$ gaseous ozone was passed through the glass column at a flow rate of $1.0 \mathrm{dm}^{3} / \mathrm{min}$ for $1 \mathrm{~h}$.

\section{3 Adsorption experiments}

To examine the saturation amount of BSA adsorbed $\left(\Gamma_{\text {sat }}\right)$ on stainless steel particles, adsorption experiment was conducted in a $0.025 \mathrm{dm}^{3}$ glass vial at $40^{\circ} \mathrm{C}$ and at the pzcapp of BSA ( $\mathrm{pH}$ 5.0) for $2 \mathrm{~h}$, using a BSA solution of $5 \mathrm{~g} / \mathrm{dm}^{3}$ in the presence of $10^{-3} \mathrm{M} \mathrm{KNO}_{3}$ as described previously ${ }^{11)}$. The $\Gamma_{\text {sat }}$ was determined as the sum of the amount of BSA removed and that of BSA still remaining on the particles after treatment with $0.1 \mathrm{M} \mathrm{NaOH}$ solution as described previously ${ }^{11}$.

To prepare BSA-fouled stainless steel particles, $0.025 \mathrm{dm}^{3}$ of BSA solution and $5 \mathrm{~g}$ of stainless steel particles were put into a $0.125 \mathrm{dm}^{3}$ glass vial, which was then reciprocally shaken (140 oscillations per minute) for $2 \mathrm{~h}$. To unify the initial amount of BSA adsorbed $\left(\Gamma_{0}\right)$ on each of the pretreated particles with or without ozone treatment, initial concentration of BSA solution was controlled based on the adsorp- tion isotherm. After being shaken for $2 \mathrm{~h}$, BSAstainless steel suspension was transferred into 0.05 $\mathrm{dm}^{3}$ of centrifugation tube, and BSA-fouled particles were collected by centrifugation $(2,300 \times \mathrm{g}$ for $1 \mathrm{~min})$. The BSA-fouled particles collected were washed 5 times with $0.025 \mathrm{dm}^{3}$ of deionized water by centrifugation $(2,300 \times \mathrm{g}$ for $1 \mathrm{~min})$. The thus obtained BSAfouled particles were dried at $40{ }^{\circ} \mathrm{C}$ for $16 \mathrm{~h}$ and stored in a desiccator before use in the cleaning experiment.

When BSA-fouled stainless steel particles were immersed in $10^{-3} \mathrm{M} \mathrm{KNO}_{3}$ solution at $40^{\circ} \mathrm{C}$ for $2 \mathrm{~h}$, no desorption of BSA occurred, indicating that the adsorption of BSA on the surface-treated stainless steel particles was irreversible.

\section{4 Cleaning experiment}

The cleaning experiment was conducted at $40^{\circ} \mathrm{C}$ in a plug-flow column fed by a $0.1 \mathrm{M} \mathrm{NaOH}$ solution as described previously ${ }^{12)}$. A $1-\mathrm{g}$ potion of the dried BSA-fouled stainless steel particles were packed into stainless steel column $(4 \mathrm{~mm} \phi \times 50 \mathrm{~mm})$, which was then installed vertically in a column oven. Rinse solution $\left(10^{-3} \mathrm{M} \mathrm{KNO}_{3}\right.$, pH 5.2) and the $\mathrm{NaOH}$ solution were fed from the bottom of the column at a flow rate of $2.5 \times 10^{-4} \mathrm{dm}^{3} / \mathrm{min}$ (space time $: 2.0 \mathrm{~min}$ ) for $120 \mathrm{~min}$, respectively. The particles were then withdrawn from the column and the amount of BSA remaining on the particles was determined. The amount of residual BSA on the particles at any time was calculated from the amount of BSA desorbed and that of BSA remaining on the particles ${ }^{13)}$. The desorption curve was obtained by plotting the logarithm of the amount of residual BSA against cleaning time (see below).

\section{5 Kinetic analysis}

To analyze the nonlinear curve of BSA desorption, the concept that two first-order reactions occur independently and simultaneously during the cleaning process was used ${ }^{14)}$ :

$\ln \Gamma=\ln \left\{\exp \left(\ln \Gamma_{0}{ }^{\mathrm{f}}-\boldsymbol{k}^{\mathrm{f}} t\right)+\exp \left(\ln \Gamma_{0}^{\mathrm{s}}-\boldsymbol{k}^{\mathrm{s}} \boldsymbol{t}\right)\right\} \quad \cdots(1)$ where $\Gamma, \Gamma_{0}{ }^{\mathrm{f}}$, and $\Gamma_{0}{ }^{\mathrm{s}}$ are the amount of adsorbed BSA at any given time $t$, and the amounts of a fasterdesorbing BSA $\left(\mathrm{BSA}^{\mathrm{f}}\right)$, and a slower-desorbing BSA $\left(\mathrm{BSA}^{\mathrm{s}}\right)$ at zero time, respectively ; $k^{\mathrm{f}}$ and $k^{\mathrm{s}}$ are the desorption rate constants of $\mathrm{BSA}^{\mathrm{f}}$ and $\mathrm{BSA}^{\mathrm{s}}$, respectively. The $k^{\mathrm{f}}$ and $k^{\mathrm{s}}$ values reflect the rates of BSA desorption in the initial and later stages of cleaning, respectively. $\quad \Gamma_{0}{ }^{\mathrm{s}}$ includes the amount of BSA remaining on the particles after 120 -min cleaning $\left(\Gamma_{\mathrm{r}}\right)$. The kinetic constants were calculated by a data-fitting procedure based on a nonlinear least-squares regression $\operatorname{method}^{14)}$.

\section{6 Analytical procedures}

The BSA concentration was measured by the dyebinding method as described previously ${ }^{14)}$. The apparent surface charge density $\left(\sigma_{\mathrm{app}}\right)$ of stainless steel particles were determined by potentiometric titration as described previously ${ }^{11)}$. The chemical composition of the outermost surfaces of stainless steel particles was determined by X-ray photoelectron spectroscopy (JPS-9200 ; JEOL Ltd., Tokyo) using a 
monochromatized $\mathrm{AlK}_{\alpha}$ radiation at $300 \mathrm{~W}(12 \mathrm{kV})$. For the analysis, stainless steel particles were molded into a plate $(13 \mathrm{~mm}$ diameter $\times 1 \mathrm{~mm}$ thickness $)$ by compression (40 MPa, $2 \mathrm{~min}$ ).

\section{7 Statistical analysis}

All experiments of adsorption and cleaning were replicated three times for each of the samples. The $\Gamma$ sat, $\Gamma_{0}, \Gamma_{\mathrm{r}}$, and kinetic constants of eq. 1 were represented as the mean value \pm standard deviation (SD). Significant differences in the mean values were determined with $t$ test at the level of $P<0$. 05 .

\section{Results}

3. 1 Characterization of surface-pretreated stainless steel particles

Table 1 shows the atomic composition of main metal components of the outermost surfaces of the dried, treated, and $\mathrm{HNO}_{3}$-treated stainless steel particles before and after $0.2 \%$ ozone treatment. Large differences were observed in the surface atomic composition depending on pretreatment method. Compared with the atomic composition of nonsurface-treated particles, heat-drying at $150^{\circ} \mathrm{C}$ exerted no influence on the surface chemical composition, whereas pretreatments with heating at $400^{\circ} \mathrm{C}$ and $10 \%$

Table 1 Atomic compositon of the surface-pretreated stainless steel particles before and after $0.2 \mathrm{vol} \%$ gaseous ozone treatment.

\begin{tabular}{lrrrr}
\hline \multirow{2}{*}{ Stainless steel } & \multicolumn{5}{c}{ Component (atom \%) } \\
\cline { 2 - 5 } & \multicolumn{1}{c}{$\mathrm{Fe}$} & $\mathrm{Cr}$ & $\mathrm{Ni}$ & $\mathrm{O}$ \\
\hline Non-surface-treated & 6.7 & 6.5 & $\mathrm{ND}^{\mathrm{a}}$ & 78.0 \\
Pretreatment & & & & \\
$\quad$ Dried $\left(150^{\circ} \mathrm{C}\right)$ & 7.0 & 6.5 & $\mathrm{ND}$ & 77.6 \\
$\quad$ Heated $\left(400^{\circ} \mathrm{C}\right)$ & 5.0 & 3.2 & $\mathrm{ND}$ & 75.1 \\
$10 \% \mathrm{HNO}_{3}$-treated & & & & \\
Pretreatment $+0.2 \%$ ozone & 6.7 & 6.3 & $\mathrm{ND}$ & 77.9 \\
$\quad$ Dried $\left(150^{\circ} \mathrm{C}\right)$ & 10.1 & 2.6 & $\mathrm{ND}$ & 76.5 \\
$\quad$ Heated $\left(400^{\circ} \mathrm{C}\right)$ & 5.8 & 10.1 & $\mathrm{ND}$ & 75.4 \\
$10 \% \mathrm{HNO}_{3}$-treated & & & & \\
\hline
\end{tabular}

${ }^{\text {a }}$ ND : not detected.

Gaseous ozone $(0.2$ vol \%) treatment was conducted at room temperature for $60 \mathrm{~min}$.
$\mathrm{HNO}_{3}$ resulted in the enrichment of iron and chromium in their surfaces, respectively. On the other hand, as a result of ozone treatment, no significant variations in the surface chemical composition were found in all the pretreated particles.

Figure 1 shows the $\sigma_{\text {app }}$ curves of non-surface treated, dried, heated, and $\mathrm{HNO}_{3}$-treated stainless steel particles as a function of $\mathrm{pH}$ before and after $0.2 \%$ ozone treatment. The pzcapp of non-surface-treated particles was found to be 9.8 (Fig. 1A). Pretreatments with heat-drying at $150^{\circ} \mathrm{C}$, heating at $400^{\circ} \mathrm{C}$, and $10 \% \mathrm{HNO}_{3}$ resulted in the shifts in the pzc'sapp to 9.0 , 7. 3, and 6.0, respectively (Figs. 1B, 1C, and 1D). The $\sigma_{\text {app }}$ curves of heated and $\mathrm{HNO}_{3}$-treated particles were characterized by low absolute values of positive and negative $\sigma_{\text {app }}$ over the $\mathrm{pH}$ range of 4 to 10 compared with the curves of dried particles. In all cases of the pretreated particles, the $\sigma_{\text {app }}$ curves were shifted to the acidic side after conducting ozone treatment. As a consequence, the pzc'sapp of ozone-treated particles were situated at points corresponding to more acidic $\mathrm{pH}$ values than the pzc'sapp of non-ozone-treated particles. The degrees of the shift in the pzcapp and of decrease in the absolute values of $\sigma_{\mathrm{app}}$ were more pronounced on dried particles (Fig. 1B). On the other hand, only a little change in the $\sigma_{\text {app }}$ curve of $\mathrm{HNO}_{3}$ treated particles was observed (Fig. 1D).

\section{2 Adsorption of BSA}

Experiments were designed to assess the effect of ozone treatment of the surface-pretreated stainless steel particles on BSA adsorption. To minimize the effects of electrostatic interaction between BSA molecules on their adsorption, BSA adsorption was conducted at the pzcapp of BSA, i. e., pH 5. 0, where all the particles were positively charged. Table 2 shows the saturation amounts of BSA adsorbed $\left(\Gamma_{\text {sat }}\right)$ on, and $\sigma$ app values at $\mathrm{pH} 5.0$ of dried, heated, and $\mathrm{HNO}_{3}$ treated particles with and without $0.2 \%$ ozone treatment. Compared with the $\Gamma_{\text {sat }}\left(2.82 \mathrm{mg} / \mathrm{m}^{2}\right)$ on dried particles, a larger $\Gamma_{\text {sat }}$ of $3.78 \mathrm{mg} / \mathrm{m}^{2}$ was obtained on heated particles, whereas an extremely low $\Gamma_{\text {sat }}$ of 1.64 $\mathrm{mg} / \mathrm{m}^{2}$ was observed on $10 \% \mathrm{HNO}_{3}$-treated particles. No correlation was found between $\Gamma_{\text {sat }}$ and $\sigma_{\text {app }}$ values

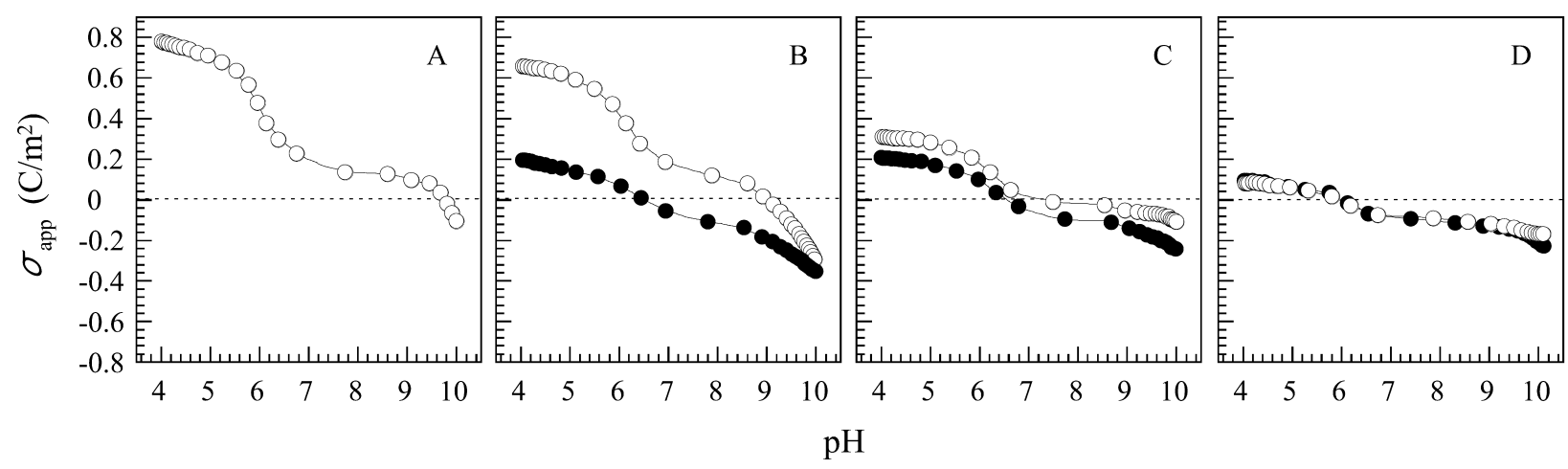

Fig. $1 \sigma_{\text {app }}$ curves of non-surface-treated and pretreated stainless steel particles as a function of pH before and after $0.2 \%$ ozone treatment. (A) Non-surface-treated particles. (B) Dried particles at $150^{\circ} \mathrm{C}$. (C) Heated particles at $400^{\circ} \mathrm{C}$. (D) $10 \%$ $\mathrm{HNO}_{3}$-treated particles. Potentiometric titration was conducted in $10^{-1} \mathrm{M} \mathrm{KNO}_{3}$ solution. Symbols : $\bigcirc$, before ozone treatment; $\mathbf{0}$, after ozone treatment. 
at pH 5.0 of non-ozone-modified pretreated particles. After conducting ozone treatment, the $\Gamma_{\text {sat }}$ on dried particles decreased significantly $(P<0.05)$, whereas $\Gamma$ sat values on heated and $\mathrm{HNO}_{3}$-treated particles were the almost same as those on their particles before ozone treatment. The $\sigma_{\text {app }}$ value of dried particles at pH 5.0 decreased from +0.60 to $+0.15 \mathrm{C} / \mathrm{m}^{2}$ by ozone treatment. This change was relatively large compared with those observed for heated particles (from +0.28 to $+0.18 \mathrm{C} / \mathrm{m}^{2}$ ) and $\mathrm{HNO}_{3}$-treated particles (constant at $+0.06 \mathrm{C} / \mathrm{m}^{2}$ ).

3. 3 Kinetic analysis of nonlinear curve of BSA desorption

In order to simplify the comparison of the cleanability, non-ozone-modified and ozone-modified particles with the almost same $\Gamma_{0}$ value as each other were prepared for each of the pretreated particles because the rate of BSA desorption depends on $\Gamma_{0}$ values $^{12), 14)}$. Figure 2 compares curves of BSA desorption from non-ozone-modified and ozone-modified dried, heated, and $\mathrm{HNO}_{3}$-treated particles, during cleaning with $0.1 \mathrm{M} \mathrm{NaOH}$ solution. In all cases of pretreated particles, the rate of BSA desorption was higher in the initial stage of cleaning and gradually

Table 2 Saturation amounts of BSA adsorbed on, and the $\sigma$ app values of surface-pretreated stainless steel particles at pH 5.0 before and after $0.2 \mathrm{vol} \%$ gaseous ozone treatment.

\begin{tabular}{lcc}
\hline \multicolumn{1}{c}{ Stainless steel } & \multicolumn{1}{c}{$\Gamma_{\text {sat }}{ }^{\mathrm{a}}$} & $\sigma_{\text {app }}$ \\
\cline { 2 - 3 } & \multicolumn{1}{c}{$\left(\mathrm{mg} / \mathrm{m}^{2}\right)$} & $\left(\mathrm{C} / \mathrm{m}^{2}\right)$ \\
\hline Dried $\left(150^{\circ} \mathrm{C}\right)$ & $2.82 \pm 0.10$ & 0.60 \\
Dried $\left(150^{\circ} \mathrm{C}\right)+0.2 \%$ ozone & $2.07 \pm 0.12$ & 0.15 \\
Heated $\left(400^{\circ} \mathrm{C}\right)$ & $3.78 \pm 0.10 \mathrm{~A}$ & 0.28 \\
Heated $\left(400^{\circ} \mathrm{C}\right)+0.2 \%$ ozone & $3.91 \pm 0.21 \mathrm{~A}$ & 0.18 \\
$10 \% \mathrm{HNO}_{3}$-treated & $1.64 \pm 0.06 \mathrm{~B}$ & 0.06 \\
$10 \% \mathrm{HNO}_{3}$-treated $+0.2 \%$ ozone & $1.62 \pm 0.02 \mathrm{~B}$ & 0.06 \\
\hline
\end{tabular}

${ }^{a}$ Mean value \pm SD of the triplicated experiments.

Mean values marked with the same letter represent data that are not significantly different $(\mathrm{P}<0.05)$.

BSA adsorption was conducted at $40^{\circ} \mathrm{C}$ and at $\mathrm{pH}$ 5.0. decreased as the residual amount of BSA decreased toward the later stage of cleaning. Significant differences, however, were observed in the curves of nonozone-modified and ozone-modified particles. Each of the ozone-modified particles apparently showed a higher rate of BSA desorption and a smaller amount of BSA remaining on the particles after 120 -min cleaning $\left(\Gamma_{\mathrm{r}}\right)$ than their non-ozone-modified particles. The solid lines in Fig. 2 were derived from the computer analysis using eq. 1 based on a nonlinear regression method. For each nonlinear curve, a fairly good fit of eq. 1 to the experimental data was obtained (multiple coefficient $: R>0.998$ ). The estimated constants of eq. 1 for each curve are summarized in Table 3. In all cases of the pretreatment particles, significantly smaller values of $\Gamma_{0}{ }^{\mathrm{s}}$ and $\Gamma_{\mathrm{r}}$ were obtained on the ozone-modified particles $(P<0.05)$. This indicated that the proportion of $\Gamma_{0}{ }^{\mathrm{s}}$, i. e., slowerdesorbing $\mathrm{BSA}^{\mathrm{s}}$, to the whole adsorbed BSA molecules on stainless steel particles decreaseed by surface modification with gaseous ozone. In the case of dried particles, the $k^{\mathrm{f}}$ and $k^{\mathrm{s}}$ values for ozone-modified particles were 1.9-fold and 1. 2-fold higher than those for non-ozone-modified particles although there was no significant difference $(P<0.05)$ in the $k^{\mathrm{s}}$. Both the $k^{\mathrm{f}}$ and $k^{\mathrm{s}}$ values for ozone-modified $\mathrm{HNO}_{3}$-treated particles were significantly higher than those for nonozone-modified particles $(P<0.05)$. On the other hand, in the case of heated particles, only the $k^{\text {s }}$ increased significantly $(P<0.05)$, whereas the $k^{\mathrm{f}}$ was hardly changed.

\section{Discussion}

The results showed that the cleanability of stainless steel particles with various surface chemical composition during cleaning with $0.1 \mathrm{M} \mathrm{NaOH}$ solution could be improved by the surface modification with gaseous ozone. Apparently, the cleanability of stainless steel particles depends both on the magnitude of forces of interaction between BSA and stainless steel surfaces, and on the susceptibility of their surfaces to the clean-
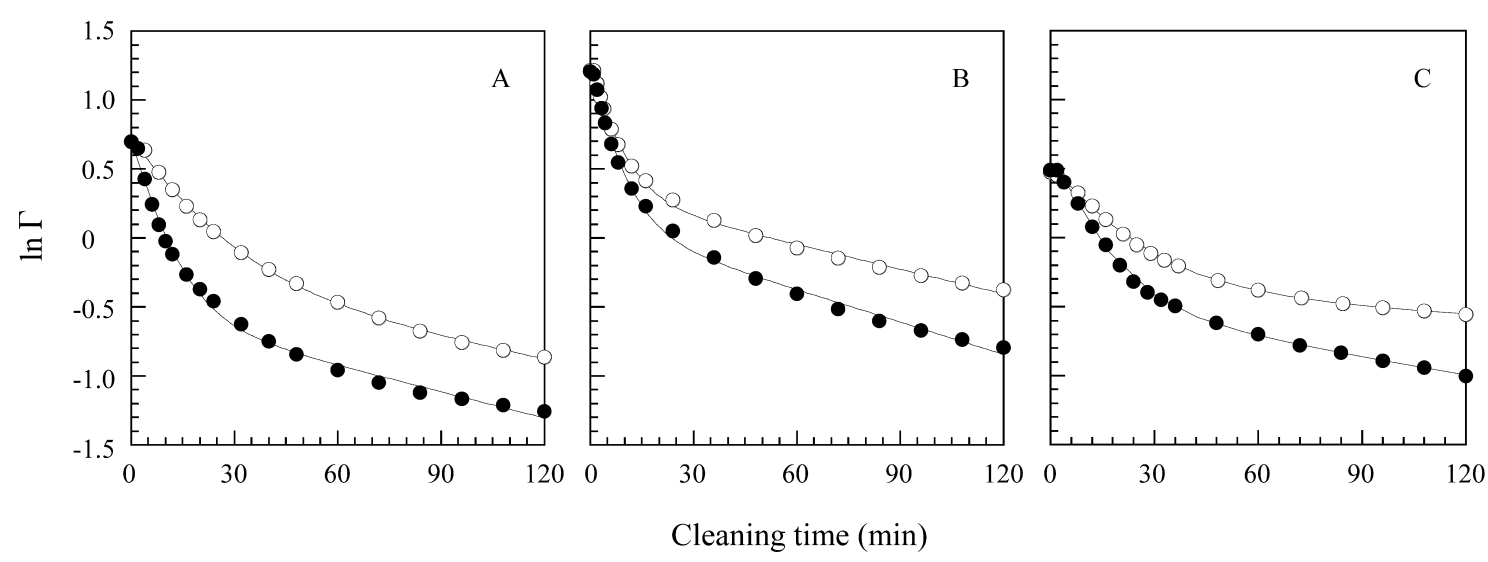

Fig. 2 Curves characterizing the desorption of BSA from non-ozone-modified and ozone-modified stainless steel particles during cleaning with $0.1 \mathrm{M} \mathrm{NaOH}$ solution. (A) Dried particles at $150^{\circ} \mathrm{C}$. (B) Heated particles at $400^{\circ} \mathrm{C}$. (C) $10 \% \mathrm{HNO}_{3}$-treated particles. Cleaning experiment was carried out at $40^{\circ} \mathrm{C}$ in a stainless steel column by feeding the $\mathrm{NaOH}$ solution at space time of 2.0 min. Symbols : $\bigcirc$, non-ozone-modified particles; 9 , ozone-modified particles. 
Table 3 Kinetic constants ${ }^{\mathrm{a}}$ of eq. 1 derived from data-fitting procedure and measurement values ${ }^{\mathrm{a}}$ of $\Gamma$ ${ }_{0}$ and $\Gamma_{\mathrm{r}}$

\begin{tabular}{|c|c|c|c|c|c|c|}
\hline \multirow{2}{*}{ Stainless steel } & $\Gamma_{0}$ & $\Gamma_{\mathrm{r}}$ & $\Gamma_{0}{ }^{\mathrm{f}}$ & $\Gamma_{0}^{\mathrm{s}}$ & $k^{f}$ & $\mathrm{k}^{\mathrm{s}}$ \\
\hline & & $\left(\mathrm{mg} / \mathrm{m}^{2}\right)$ & \multicolumn{2}{|c|}{$\left(\mathrm{mg} / \mathrm{m}^{2}\right)$} & \multicolumn{2}{|c|}{$\left(\min ^{-1}\right)$} \\
\hline Dried $\left(150^{\circ} \mathrm{C}\right)$ & $\begin{array}{l}2.06 \\
\pm 0.05 \mathrm{~A}\end{array}$ & $\begin{array}{l}0.41 \\
\pm 0.02\end{array}$ & $\begin{array}{l}1.21 \\
\pm 0.04 \mathrm{~A}^{\prime}\end{array}$ & $\begin{array}{l}0.84 \\
\pm 0.01\end{array}$ & $\begin{array}{l}0.062 \\
\pm 0.001\end{array}$ & $\begin{array}{l}0.0064 \\
\pm 0.0001 \mathrm{~A}\end{array}$ \\
\hline Dried $\left(150^{\circ} \mathrm{C}\right)+0.2 \%$ ozone & $\begin{array}{l}2.07 \\
\pm 0.11 \mathrm{~A}\end{array}$ & $\begin{array}{l}0.28 \\
\pm 0.01\end{array}$ & $\begin{array}{l}1.41 \\
\pm 0.14 \mathrm{~A}^{\prime}\end{array}$ & $\begin{array}{l}0.67 \\
\pm 0.09\end{array}$ & $\begin{array}{l}0.12 \\
\pm 0.01\end{array}$ & $\begin{array}{l}0.0077 \\
\pm 0.0012 \mathrm{~A}\end{array}$ \\
\hline Heated $\left(400^{\circ} \mathrm{C}\right)$ & $\begin{array}{l}3.27 \\
\pm 0.09 \mathrm{~B}\end{array}$ & $\begin{array}{l}0.68 \\
\pm 0.06\end{array}$ & $\begin{array}{l}1.84 \\
\pm 0.16\end{array}$ & $\begin{array}{l}1.43 \\
\pm 0.08\end{array}$ & $\begin{array}{l}0.16 \\
\pm 0.02 \mathrm{~B}\end{array}$ & $\begin{array}{l}0.0065 \\
\pm 0.0006\end{array}$ \\
\hline Heated $\left(400^{\circ} \mathrm{C}\right)+0.2 \%$ ozone & $\begin{array}{l}3.33 \\
\pm 0.02 \mathrm{~B}\end{array}$ & $\begin{array}{l}0.47 \\
\pm 0.02\end{array}$ & $\begin{array}{l}2.22 \\
\pm 0.02\end{array}$ & $\begin{array}{l}1.11 \\
\pm 0.04\end{array}$ & $\begin{array}{l}0.16 \\
\pm 0.02 \mathrm{~B}\end{array}$ & $\begin{array}{l}0.0078 \\
\pm 0.0001\end{array}$ \\
\hline $10 \% \mathrm{HNO}_{3}$-treated & $\begin{array}{l}1.62 \\
\pm 0.05 \mathrm{C}\end{array}$ & $\begin{array}{l}0.59 \\
\pm 0.02\end{array}$ & $\begin{array}{l}0.89 \\
\pm 0.07 \mathrm{C}^{\prime}\end{array}$ & $\begin{array}{l}0.73 \\
\pm 0.06\end{array}$ & $\begin{array}{l}0.053 \\
\pm 0.004\end{array}$ & $\begin{array}{l}0.0019 \\
\pm 0.0005\end{array}$ \\
\hline $10 \% \mathrm{HNO}_{3}$-treated $+0.2 \%$ ozone & $\begin{array}{l}1.62 \\
\pm 0.02 \mathrm{C}\end{array}$ & $\begin{array}{l}0.37 \\
\pm 0.01\end{array}$ & $\begin{array}{l}1.00 \\
\pm 0.05 \mathrm{C}^{\prime}\end{array}$ & $\begin{array}{l}0.62 \\
\pm 0.03\end{array}$ & $\begin{array}{l}0.082 \\
\pm 0.005\end{array}$ & $\begin{array}{l}0.0046 \\
\pm 0.0006\end{array}$ \\
\hline
\end{tabular}

${ }^{\mathrm{a}}$ Mean value $\pm \mathrm{SD}$ of the triplicated experiments.

Mean values marked with the same letter represent data that are not significantly different $(\mathrm{P}<0.05)$.

Cleaning was conducted in a plug-flow column at $40^{\circ} \mathrm{C}$ by feeding $0.1 \mathrm{M} \mathrm{NaOH}$.

ing action of the $\mathrm{NaOH}$ solution.

The $\Gamma_{\text {sat }}$ values on dried, heated, $\mathrm{HNO}_{3}$-treated stainless steel particles ranged between 1.6 and 3.8 $\mathrm{mg} / \mathrm{m}^{2}$. Norde and Giacomelli ${ }^{15)}$ calculated the maximum amount of BSA adsorbed of ca. $4 \mathrm{mg} / \mathrm{m}^{2}$ for a closely packed monolayer on solid surfaces by assuming that the BSA molecule can be approximated by an equilateral triangle with a side of $\sim 8 \mathrm{~nm}$ and a depth of $\sim 3 \mathrm{~nm}$. The $\Gamma_{\text {sat values obtained in this study was }}$ less than this calculated value. In addition, BSA was adsorbed onto all of the particles in an irreversible fashion. These findings suggest that BSA molecules $\left(\mathrm{BSA}^{\mathrm{f}}\right.$ plus $\mathrm{BSA}^{\mathrm{s}}$ ) are directly adsorbed on the particles within a monolayer coverage.

Ozone treatment changed the $\sigma_{\text {app }}$ curve of dried particles considerably, but not the surface chemical composition. The $\Gamma_{\text {sat }}$ on ozone-modified dried particles was significantly less than that on their nonozone-modified particles. These results were in good agreement with our previous studies ${ }^{11,16}$. The facts that the shift in the pzcapp to the acidic side and decrease in the positive values of $\sigma_{\mathrm{app}}$ occurred by ozone treatment were due to the removal of surface $\mathrm{OH}$ groups, especially the base $\mathrm{OH}$ groups $\left(\mathrm{M}^{-}-\mathrm{OH}_{2}{ }^{+}\right)$, by oxidative action of gaseous ozone $\mathrm{e}^{11,17}$. The base $\mathrm{OH}$ groups, i. e., the surface $\mathrm{OH}$ groups singly coordinated to the metal ion, act as the adsorption site for carboxyl groups on organic acids ${ }^{18)}$. BSA is also adsorbed on positively charged stainless steel surfaces $\left(\mathrm{M}-\mathrm{OH}_{2}{ }^{+}\right)$through varying numbers of carboxyl groups on the molecule ${ }^{19}$. Therefore, the decrease in $\Gamma_{\text {sat }}$ on the dried particles could be interpreted as arising from the decrease in the positive $\sigma_{\mathrm{app}}$ of stainless steel particles at $\mathrm{pH}$ 5.0. The $\Gamma_{\text {sat }}$ values on ozone-modified, heated, and $\mathrm{HNO}_{3}$-treated particles were the almost same as those on their non-ozonemodified particles, respectively. According to the above discussion, this was probably due to that ozone treatment of heated and $\mathrm{HNO}_{3}$-treated particles resulted in only slight changes in their surface chemical composition and the $\sigma_{\text {app }}$ values. On the other hand, the $\Gamma_{\text {sat }}$, expressed as mass, was not always correlated with the magnitude of the forces of interaction between BSA and stainless steel surfaces. Kinetic analysis of curves of BSA desorption showed that significantly smaller proportions of $\Gamma_{0}{ }^{\mathrm{s}}$ (including $\Gamma_{\mathrm{r}}$ ) to $\Gamma_{0}$, and significantly higher values of at least either $k^{\mathrm{f}}$ or $k^{\mathrm{s}}$ were obtained for all the ozone-modified particles $(P<0.05)$ when compared at the same $\Gamma_{0}$ values as those on the non-ozone-treated particles (Table 3). These findings indicated that the binding strength of BSA on the ozone-modified particles was smaller than that on their non-ozone-modified particles, even if there was no significant difference in the $\Gamma_{\text {sat values. }}$ It is reasonable that the binding strength of BSA depends on the number of attached carboxyl groups on $\mathrm{BSA}^{20)}$. A small $\sigma_{\text {app }}$ value of ozonemodified particles allow a conformation of BSA with less interaction points and hence weak interactions with BSA. These BSA molecules are more rapidly desorbed by cleaning with the $\mathrm{NaOH}$ solution. Thus, controlling the $\sigma_{\text {app }}$ value of stainless steel particles was found to be one of important factors improving their cleanability.

Besides the magnitude of the BSA-stainless steel interactions, another factor governing the cleanability is the electrostatic repulsive action of stainless steel surfaces against the adsorbed BSA molecule. It has been pointed out that the primary function of cleaning chemicals is to minimize the magnitude of attractive forces between soil and solid surface by adsorption of cleaning chemicals both on soil and on solid surface, and that preferential displacement is one of the principal cleaning mechanisms ${ }^{21)}$. The detergency of $\mathrm{NaOH}$ solution is due to the action of $\mathrm{OH}^{-}$ions. High concentrations of $\mathrm{OH}^{-}$ions enhance the degrees of solubility and dispersion of adsorbed BSA molecule in the $\mathrm{NaOH}$ solution. In addition, $\mathrm{OH}^{-}$ions cause deprotonation (i. e., adsorption of $\mathrm{OH}^{-}$) of acid surface groups on stainless steel particles and BSA. As a 
result, BSA and stainless steel surfaces are more negatively charged, creating the electrostatic repulsive forces between BSA and stainless steel surfaces. Large negative $\sigma_{\text {app }}$ values of stainless steel particles at alkaline conditions are equivalent to the presence of large numbers of adsorption site for $\mathrm{OH}^{-}$ions. Therefore, the surfaces showing large-negative charge are susceptible to the cleaning action of $\mathrm{OH}^{-}$ions and they give greater repulsive forces toward BSA, thereby accelerating BSA desorption and reducing the $\Gamma_{\mathrm{r}}$. In this study, ozone-modified dried and ozone-modified heated particles showed larger negative $\sigma_{\text {app }}$ values at alkaline $\mathrm{pH}$ region than their non-ozone-modified particles except for the case of $\mathrm{HNO}_{3}$-treated particles (Fig. 1). The $\sigma_{\text {app }}$ value could not be measured in 0.1 $\mathrm{NaOH}$ solution ( $\mathrm{pH}$ 13) by potentiometric titration. Nevertheless, it was suggested that elevated repulsive forces on ozone-modified particles are responsible for a decrease in $\Gamma_{\mathrm{r}}$ and an increase in the $k^{\mathrm{s}}$. It was noted that relatively larger $\Gamma_{\mathrm{r}}$ values were obtained on heated and $\mathrm{HNO}_{3}$-treated particles although $\Gamma_{\text {sat }}$ values were different from each other. It has been reported that cleanability of $20 \% \mathrm{HNO}_{3}$-treated $316 \mathrm{~L}$ stainless steel surfaces fouled with $\beta$-lactoglobulin during cleaning with $0.25 \mathrm{M} \mathrm{NaOH}$ solution were lower than non- $\mathrm{HNO}_{3}$-treated surfaces ${ }^{22), 23)}$. It is assumed that heated and $\mathrm{HNO}_{3}$-treated particles could not give great repulsive forces toward BSA because their particles were less negatively charged at alkaline $\mathrm{pH}$ region. In a practical cleaning, it is desirable to accelerate the rate of the later stage of cleaning $\left(k^{\mathrm{s}}\right)$, and reduce the amount of soils remaining on stainless steel surfaces $\left(\Gamma_{\mathrm{r}}\right)$. These requirements were fulfilled to some extent by surface modification of stainless steel particles by gaseous ozone.

In this paper, the point of the argument was focused on the comparison of the cleanabilities only of each of the pretreated particles before and after ozone treatment, but not among the pretreated particles. Studies on the influence of the enrichment of $\mathrm{Fe}$ or $\mathrm{Cr}$ in the passive film on stainless steel particles on the degree of fouling and cleanability are also in progress and will be reported elsewhere.

\section{Conclusions}

In this study, the cleanabilities of non-ozonemodified and ozone-modified stainless steel particles with various surface properties were compared by evaluating the kinetic constants for BSA desorption in a plug-flow column fed by a $0.1 \mathrm{M} \mathrm{NaOH}$ solution.
Kinetic analysis showed that the cleanability of stainless steel particles could be improved by gaseous ozone treatment irrespective of the surface chemical composition of the original particles. It was concluded that modification of the $\sigma_{\text {app }}$ value by ozone could induce a reduction of the binding strength of BSA and an increase in electrostatic repulsion forces between BSA and stainless steel surfaces in the $\mathrm{NaOH}$ solution.

(Received September 29, 2005 ; Accepted January 24, 2006)

\section{References}

1) J. R. Davis ; ASM handbook, Vol. 5, p.741 (ASM International Material Park, Ohaio, 1994)

2 ) European Hygienic Equipment Design Group ; Trends Food Sci. Technol., 4, 225 (1993)

3 ) J. E. Sundgren, P. Bodo, I. Lundstrom, A. Berggren and S. Hellem ; J. Biomed. Mater. Res., 19, 663 (1985)

4) O. Suzuki ; Encyclopedia of Surface and Colloid Science, p. 167 (Marcel Dekker Inc., NY, 2002)

5 ) D. A. Timperley ; J. Soc. Dairy Technol., 34, 6 (1981)

6 ) T. L. Grimes, D. E. Fonner, J. C. Griffen and L. R. Rathbun ; Bull. Parenter. Drug Assoc., 29, 64 (1975)

7 ) A. Rossi and B. Elsener ; Mater. Sci. Forum., 185, 337 (1995)

8 ) S. Virtanen and H. Bohni ; Mater. Sci. Forum., 185, 965 (1995)

9 ) H. Urano and S. Fukuzaki ; J. Food Prot., 64, 108 (2001)

10) G. Moore, C. Griffith and A. Peters ; J. Food Prot., 63, $1100(2000)$

11) S. Fukuzaki, H. Urano, M. Hiramatsu and A. Takehara ; Biocontrol Sci., 6, 87 (2001)

12) K. Takahashi and S. Fukuzaki ; Biocontrol Sci., 8, 111 (2003)

13) H. Urano and S. Fukuzaki ; Biocontrol Sci., 10, 21 (2005)

14) H. Urano and S. Fukuzaki ; J. Colloid Interface Sci., 252, 284 (2002)

15) W. Norde and C. E. Giacomelli ; J. Biotechnol., 79, 259 (2000)

16) S. Fukuzaki, H. Urano, M. Hiramatsu and A. Takehara ; Biocontrol Sci., 6, 95 (2001)

17) S. Fukuzaki, A. Atsuhiko, K. Takahashi, M. Hiramatsu and K. Koike; J. Surface Finish Soc. Jpn., 54, 1034 (2003)

18) J. D. Filius, T. Hiemstra and W. H. Van Riemsdijk ; $J$. Colloid Interface Sci., 195, 368 (1997)

19) S. Fukuzaki, H. Urano and M. Hiramatsu ; J. Surface Finish Soc. Jpn., 49, 1237 (1998)

20) S. Fukuzaki ; Bokin Bobai, 32, 203 (2004)（in Japanese)

21) W. G. Jennings ; Advances in Food Research, , Vol. 14, p. 325 (Academic Press, NY, 1965)

22) C. A.-C. Karlsson, M. C. Wahlgren, C.-O. A. Olsson and A. C. Trägårdh ; J. Colloid Interface Sci., 220, 471 (1999)

23) C. A.-C. Karlsson, M. C. Wahlgren and A. C. Trägårdh ; Int. Dairy J., 8, 925 (1998) 